$A D D I N$, Volume 11, Number 1, February 2017

\title{
IN BETWEEN ISLAMIC BOARDING SCHOOL: a Study of al-Mubarok al-Islam within the Social Changes of Seberang Kota Jambi
}

\author{
Edy Kusnadi, Kadir Sobur, and Arfan Aziz \\ IAIN Sulthan Thaha Saifuddin Jambi \\ edykusnadi2008@yahoo.co.id
}

\begin{abstract}
This research was conducted to search the meaning of traditional Islamic boarding schools in Seberang Kota Jambi as an existence legacy of religious traditional institutions in Jambi Malay modern world. The boarding school were slow adapt the modern developments and considered as an educational institution "conservative" who only teach "sky" science by forgetting bis footing on the earth. The author tries to conduct a research to determine how the response of a salafiyah Islamic boarding school named al-Mubarok al-Islam toward social change, and how its success. Through a field research and descriptive qualitative method, data were collected through observation, interviews and documentation. The results of research include: First, al-Mubarok. al-Islam salafiyah Islamic boarding schools has been growing and has a formal structure that can accommodate all aspects of the pesantren.
\end{abstract}


Second, al-Mubarok al-Islam salafiyah Islamic boarding schools began to provide an opportunity for its students to be able to follow modern world by facilitating them in the national exam and have a certificate in general that can be used in the workplace in general. Third, alMubarok al-Islam salafiyah Islamic boarding schools provides the opportunity for students to be able to learn information communication technology nowadays.

Keywords: Salafiyah Boarding School, al-Mubarok al-Islam, Jambi, Modern World.

\section{Abstrak}

Penelitian ini dilakukan untuk meendalami perubahan pesantren tradisional di Seberang Kota Jambi sebagai warisan keberadaan lembaga keagamaan tradisional dalam dunia Jambi modern. Pondok pesantren yang lambat beradaptasi dengan perkembangan modern dan dianggap sebagai lembaga pendidikan "konservatif" yang hanya mengajarkan ilmu pengetahuan "langit" dan melupakan pijakan di bumi. Penulis mencoba untuk melakukan penelitian untuk. menentukan bagaimana respons pesantren salafiyah yang bernama al-Mubarok al-Islam menuju perubahan sosial dan bagaimana keberhasilannya. Penelitian lapangan dilakukan dengan pendekatan deskriptif kualitatif, yaitu melalui observasi, wawancara, dan dokumentasi. Hasil penelitian menyatakan: Pertama, Pondok Pesantren Salafiyah al-Mubarok al-Islam telah berkembang dan memiliki struktur formal yang dapat mengakomodasi semua aspek. dari pesantren. Kedua, Pondok Pesantren Salafiyah al-Mubarok al-Islam mulai memberikan kesempatan bagi siswa untuk dapat mengikuti dunia modern dengan memfasilitasi mereka dalam ujian nasional dan memiliki sertifikat pada umumnya yang dapat digunakan di tempat kerja pada umumnya. Ketiga, Pondok Pesantren Salafiyah al-Mubarok al-Islam memberikan kesempatan bagi siswa untuk dapat belajar teknologi komunikasi informasi saat ini.

Kata Kunci: Pondok Pesantren Salafiyah, al-Mubarok al-Islam, Jambi, Dunia Modern. 


\section{A. Introduction}

Boarding schools are one of Indonesia's oldest Islamic educational institutions, which became a central for pure religious activities (tafaqquh $\bar{f} i$ ad-din) to spread Islam. That was the identity of boarding schools during their early stages of development. The boarding school's education system was based, practiced, and led by the values based on the fundamentals of Islam. These Islamic values became one with contextual structure or the applied social reality in everyday lives. They also became the base of boarding schools' building concept and their role as an institution. ${ }^{2}$

The region of Seberang Kota Jambi (Sekoja), Jambi Province, was known as one of the central Islamic education and development. It is marked by the large amount of Islamic schools (which turned into Islamic boarding schools), ${ }^{3}$ and the number ancient mosques in Sekoja. In Jambi, the huge amount of Islamic schools in Sekoja made it known as "kota santri" (the city of students). One of the existing salafiyah boarding schools is the al-Mubarok al-Islam which is located in Jl. Kiyai Haji Tumenggung Jakfar, Tahatul Yaman, Kecamatan Pelayangan, Kota Jambi.

Religious values exists in Jambinese in a general manner. Jambinese are religious people, and Malayan ethnic is strongly connected with Islam. Various aspects of peoples' lives are influenced by religious manners, behaviors, and views. In Jambi, Islam is an orientation for peoples' manners, behaviors, views of life, and peoples' culture. Parents highly emphasize religious studies to their children. ${ }^{4}$ 2005), p. 4.

${ }^{2}$ Jamaludin Malik, Pemberdayaan Pesantren (Yogyakarta: Pustaka Pesantren,

${ }^{3}$ Ali Muzakir, "Madrasah atau Pesantren?: Jatidiri dan Identitas Lembaga Pendidikan Islam di Jambi", Paper on International Confrence on Jambi Studies, Jambi, November 21-24, 2013.

${ }^{4}$ Moh. Yamin, Jambi: Profil Propinsi Republike Indonesia (Jakarta: Yayasan Bhakti Wawasan Nusantara, 1992), p. 310-311. 
The existence of true Jambi Malayan in Sekoja became some sort of unique standalone society. The building of Gentala Arrsy Bridge not only became the symbol of proof of Sekoja's advanced society, but also acts as a thing that connects Jambi City and Jambi Seberang, which make the later place easier to visit.

Boarding schools are known as a traditional religious academic institution that lacks the speed to adapt and signaled as an "old-fashioned" institution which only taught the knowledge of "heavens" while forgetting their place on earth. ${ }^{6}$ Along with the development of the age, boarding schools are shifting, and forced to respond to the current changes of the world.

In their development, boarding schools evolved from the more traditionally oriented into modernly oriented, which makes nowadays boarding schools became divided into two big type of groups, the sala $\bar{f}$ (traditional) and khala $\bar{i}$ (modern). Salafi boarding schools are those which are still bound by the old system and model, while khalafi boarding schools are those which have accepted the renewal of old system by becoming a formal academic institution. ${ }^{7}$ In today's context, boarding schools received more and more changes, both positively and negatively.

The boarding schools mentioned in this writing are intended for the salafi boarding school, which maintains the teachings of classic Islamic books as the core of education. Dhofier characterize this type of boarding school as an educational institution that is strongly bound with the ideas of figh, hadist, tauhid, tafsir and tasawuf from seven

${ }^{5}$ Poerbakawatja, Pendidikan dalam Alam Indonesia (Jakarta: Gunung Agung, 1976), p. 233.

${ }^{6}$ Haidar Putra Daulay, Sejarah Pertumbuhan dan Pembaharuan Pendidikan Islam di Indonesia (Jakarta: Kencana, 2007), p. 22.

${ }^{7}$ UU No. 20 Tahun 2003 Tentang Sisdiknas, Pasal 1 ayat (11). 
to thirteenth century. ${ }^{8}$ Boarding schools are known to be conservative and closely related to traditional Islamic values, but basically still being open towards change so that boarding schools not only contain the sense of Islam, but also Indonesian originality. ${ }^{9}$

That is why, a research towards the al-Mubarok al-Islam salafiyah Islamic boarding schools become important, to gain information whether the systems applied in this boarding school is still keeping its originality with the old system, or have it opened itself while still keeping its Indonesian indigenous traditional education.

\section{B. Discussion}

\section{Concept of Islamic Boarding School in Indonesia}

In Indonesia language, the word "pondok" means room, hut, or tiny house with emphasize on the simplicity of the building. "Pesantren" basically means "the place for 'santri' (student) to learn". "Pondok" also means a simple place to live made of bamboo. Aside from that, the word "pondok" might have also derived from the Arabic "funduq" which means "hotel or dormitory". ${ }^{10}$

Boarding schools are unique educational institution with their own speciality and are different from other educational institutions. The subjects learned in boarding schools include Islamic education, dakwah, social development and other similar type of subjects. The students of boarding schools known as "santri" usually live in them. The place where Santri lives within the school's environment, are known

\footnotetext{
${ }^{8}$ Zamakhsari Dhofier, Tradisi Pesantren: Studi Tentang Pandangan Hidup Kyai (Jakarta: LP3ES, 1994), p. 1.

${ }^{9}$ Dawam Raharjo, Pergulatan Pesantren (Jakarta: P3M, 1985), p. 3.

${ }^{10}$ Zamakhsyari Dhofier, Tradisi Pesantren, p. 18.
} 
as "pondok". This is where the term "pondok pesantren" (boarding school) came from. ${ }^{11}$

Muhammad Arifin in Mujamil, gave boarding school the following definition: "an Islamic educational institution which grows and acknowledged by the surrounding societies, with dormitory system (complex) where the students received knowledge using the teaching system or Islam school which fully beneath the authority of one or several kyai's leadership, whom have charismatic and independent personalities in every matter". ${ }^{12}$

Islamic Research Institution (pesantren luhur), as quoted by Mujamil Qamar, defined boarding schools as "a place for the students to receive Islamic educations all at once becoming their place to get together and live in". Mujamil Qamar also gave a shorter definition, "an educational institution which emphasizes in religious subjects and supported with a permanent living quarters for its students". ${ }^{13}$

Boarding schools are Islamic educational institution with one or more students learning in it and led by the boarding school's leader (kyai), helped by several teachers (ulama/ustaz). There are five inseparable elements within them which is, the hut, the mosque, the teachings of blank Arabic, the students, and the kyai. These are called the boarding school's tradition, where Gus Dur describe it as a culture for boarding schools, which is a socio-religious culture that came as a result from the living interaction between hut, mosque, student, teaching of classical books, and kyai's life. ${ }^{14}$

${ }^{11}$ Departemen Agama RI, Pondok Pesantren dan Madrasah Diniyah (Jakarta: Direktorat Jenderal Kelembagaan Agama Islam, 2003), p. 1.

${ }_{12}$ Mujamil Qamar, Pesantren: dari Transformasi Metodologi Menuju Demokratisasi Institusi (Jakarta: Erlangga, 2005), p. 2.

${ }^{13}$ Ibid.

${ }^{14}$ Bahtiar Effendy, Transformasi Pemikiran dan Praktek Politik, Islam (Jakarta: Paramadina, 1998), p. 106. 
Boarding schools, as an indigenous educational institution in Indonesia, have huge role in producing high quality generation every year. Ki Hajar Dewantara says that boarding schools are the base and source of national education, since it fits with Indonesian sense of spirit and personality, such that they need to be developed, guided, and helped. ${ }^{15}$

As such, it can be concluded that boarding schools are place where the "santri" lives and receive Islamic education within the boarding school environment.

In 1979, the Minister of Education release the Rule No. 3 Year 1979 which revealed the forms of boarding schools:

a. Type A boarding schools, the type of boarding schools where the students learn and live in the dorm within the boarding school's environment and the learning happen in a traditional way.

b. Type B boarding schools, the type of boarding schools which run the learning system the classical way and the lessons given by kyai are applicative and only given on particular occasion. The students live within the boarding school's environment.

c. Type $\mathrm{C}$ boarding schools, the type of boarding schools which is only consisting of dormitories and the students learn from Islamic school outside its vicinity, while kyai only become the students' mental support and supervisor.

d. Type D boarding schools, which is a boarding school that implement both the system of traditional boarding school and an Islamic school. ${ }^{16}$

\footnotetext{
${ }^{15}$ Amin Haedari, Transformasi Pesantren: Pengembangan Aspek Pendidikan Keagamaan dan Sosial (Jakarta: LEKDIS and Media Nusantara, 2006), p. 123.

${ }^{16}$ Departemen Agama RI Direktorat Jenderal Kelembagaan Agama Islam, Direktorat Pendidikan Keagamaan dan Pondok Pesantren, Proyek
} 
In order to see the shifts in today's boarding schools from the past, we can classify them by using typology of boarding schools which once have developed, there are three of them:

a. Boarding schools are educational and teaching institution, which commonly give those teachings in a non-classical way, where a kyai teach the students based on the books written in Arabic by Islamic well known clergies since the middle ages, while students usually live in dormitories within said boarding school.

b. Boarding school is an educational institution which basically not much different from the previously said boarding schools, but the students live and are scattered within the village around the boarding school, where the method of the teaching allows the students to come in large groups in particular time.

c. Today's boarding schools are a mixture between the system the boarding school which teach Islamic religion by various ways, and the students are given the facility to live within the boarding school, or near them, in the modern boarding school essence dictates that the students are still within the criteria of a nonformal education learner, and also the boarding school provides the formal education in the form of Islamic school or even regular school in various levels and specialties depending on necessity. ${ }^{17}$

Boarding schools, as seen from the subject taught which goes along with the growth and development of boarding schools, and then we can classify the boarding schools

Peningkatan Pendidikan Luar Sekolah pada Pondok Pesantren, Pola Pengembangan Pondok Pesantren (Jakarta: Departemen Agama RI, 2003), p. 24-25.

${ }^{17}$ Hasbullah, Sejarah Pendidikan Islam di Indonesia: Lintasan Sejarah Pertumbuban dan Perkembangan (Jakarta: Raja Grafindo Press, 1999), p. 45-46. 
into three categories based on the subjects they teach: (a) traditional boarding school (salafiyah); (b) modern boarding school (khalafiyah); and (c) comprehensive boarding school. The explanation is as follows:

\section{a. Traditional Boarding School (Salafiyah)}

Traditional boarding school (salafiyah) is a boarding school that keeps its original form by only teaching the books written by clergies in $15^{\text {th }}$ century using Arabic. It teach by using the "ḅalaqah" teaching pattern, which means using discussion to understand the content of the book, not to question whether the teachings within it is right or wrong, but to understand what it's trying to teach. The students believe that the kyai will never teach them wrong things, and they are sure that the content of the book that they learned are true. ${ }^{18}$

The curriculum entirely depended on the kyai. The students consist of those who live inside and outside of the boarding school's environment. While the Islamic schools system is only applied to ease the "sorogan" system which used in old-fashioned studying institute, without introducing regular subjects taught in regular school. ${ }^{19}$ Aside from "sorogan" system, they also apply "bandongan" system. ${ }^{20}$

\section{b. Modern Boarding Schools (Khalafiyah)}

A modern boarding school (khalafiyah) is a boarding school which tried to fully implement the traditional boarding school system and combine it with modern school's system within the boarding school itself. The learning of classical books are no longer prominent, some even become only as a complementary lesson, but becoming a cultural homogeny

\footnotetext{
${ }^{18}$ Mastuhu, Dinamika Sistem Pendidikan Pesantren (Jakarta: INIS, 1994), p. 61.

${ }^{19}$ Zamakhsari Dhofier, Tradisi Pesantren, p. 42.

${ }^{20}$ W. Bakhtiar, Laporan Penelitian Perkembangan Pesantren di Jawa Barat (Bandung: Balai Penelitian IAIN Sunan Gunung Jati, 1990), p. 22.
} 
lesson, and religion will regress with the variety and complexity of modern Indonesia's social development. Even so, it is interesting since the kyai seem to have been prepared for this. ${ }^{21}$

Even though the curriculum of modern boarding schools includes the regular subjects from regular schools, it still has some religious essence in it.

\section{c. Comprehensive Boarding Schools}

Comprehensive boarding school is the mixture of traditional and modern system. The learning of blank arabic is implemented by using the "sorogan", "bandongan", and "wetonan" method, but the school systems are regularly developed.

Furthermore, social studies become its specialty, the size of the boarding school will increase along with the capacity of the workers and its reach within the society. This characteristic of boarding schools can be used to understand its nature as social resource institution. ${ }^{22}$

\section{Social Changes in Community}

To understand the meaning of social change, we need to know the definition restriction of social changes itself. ${ }^{23}$ Many philosopher and sociologist have a notion that the events of social changes are considered normal which came out from human interactions. Some think that social change happens because the element that keep the community's balance has shifted, such as the change in geography, biology, economy,

${ }^{21}$ Zamakhsari Dhofier, Tradisi Pesantren, p. 44.

${ }^{22}$ M.D. Nafi', Praktis Pembelajaran Pesantren (Yogyakarta: Institute for Training and Development Amherst, MA Forum Pesantren and Yayasan Selasih, 2007), p. 17.

${ }^{23}$ Wilbert E. Maore, Order and Change: Essay in Comparative Sosiology (New York: John Wiley and Sons, 1967), p. 3. 
and culture. There is also an opinion which states that the social changes are periodic and non-periodic in nature. ${ }^{24}$

According to John Lewis Gillin and John Philip Gillin in Abdulsyani, "Social change is a variation of accepted lifestyle. Those changes happen because of the shift in geography, cultural material, societies' composition, ideology shift, or because of diffusion or new inventions within the community." 25

According to Selo Soemardjan, the changes in social institution within the society, which fulfill their social system, including values, attitude, and behavioral pattern between the groups in society. The definition emphasizes the part of social institutions as human's main association, which then affects other social structure in community. ${ }^{26}$

Pitirim A. Sorokin thinks that an effort to suggest a certain and constant inclination in social changes would result badly. He doubts the existence of a circle of those social changes. Even so, changes keep on existing and the most important thing is that those circles need to be learned in order to achieve a generalization. ${ }^{27}$ Briefly, Samuel Koenig states that social changes refer to the modification within humans living patterns, which could have been affected by internal or external cause. ${ }^{28}$

Talcott Parson in functional theory as one of social changes' theory, emphasize that a community is integrated from an agreement of its members about certain social

${ }^{24}$ Soerjono Soekanto, Sosiologi Suatu Pengantar (Jakarta: Rajawali Pers, 2010), p. 263.

${ }_{25}$ Abdulsyani, Sosiologi: Skematika, Teori, dan Terapan (Jakarta: Bumi Aksara, 2007), p. 163. p. 376.

${ }^{26}$ Social Change in Yogyakarta (New York: Cornell University Prss, 1962),

${ }^{27}$ Pitirim A. Sorokin, Contemporary Sociologial Teories (New York: Harper and Brothers, 1928), p. 739.

${ }^{28}$ Samuel Koenig, Mand and Society: the Basic Teaching of Sociology (New York: Barners and Noble, Inc., 1957), p. 279. 
values which have the ability to solve differences so that the community may be viewed as a functional society which integrated with balance. ${ }^{29}$ According to Parson, there are four functions for all "action" system. A function is a collection of things aimed at the fulfillment of a certain need or system's need. ${ }^{30}$ Parsons then develop something that known as functional imperatives so that a system can continue to last. These imperatives are Adaptation, Goal attainment, Integration, and Latency, also known as AGIL. Parsons designed AGIL so that it can be used in all levels in a system. ${ }^{31}$ System functions' clarification, act as a patterned cultivation (as an internal tool), integration (as an internal result), goal attainment, (as an external results), and adaptation (as an external tool). Those four functions are implemented sturdily within every living being at every level of evolutionary development. ${ }^{32}$

Thus, it can be concluded that social change is a shift of social elements within a society, which create a new way of living.

\section{Factors That Affects Social Changes}

The change in society can include social values, norms, behavioral patterns, organizations, social institution, layers in the community, power and authority, social interaction, etc.

The sociologist have made a classification between the static and dinamic community. Static communities are those which are only slightly changing, and move slowly. Dynamic community are those which experience change in a fast pace.

${ }^{29}$ Alexander Stingl, The Biological Vernacular: from Kant to James, Weber, and Parsons (Lampeter: Mellen Press, 2009), p. 54-70.

${ }^{30}$ George Ritzet and Douglas J. Goodman, Teori Sosiologi Modern (Jakarta: Kencana, 2010), p. 121.

${ }^{31}$ Ibid.

${ }^{32}$ Richard Grathoff, The Correspondence between Alfred Schutz and Talcott Parsons: the Theory of Social Action (Bloomington and London: Indiana University Press, 1978), p. 67-87. 
So every community, at some point can be considered as static. On other society, they can be considered dynamic. Changes not only about progress, but also the regression of certain field of live.

Social changes can be caused from outside of the community, such as the cultural influence of another society. The changes in traditional community into modern community happen because of the influence from a modern culture. Traditional community is still bound with its tradition which they follow, and those traditions are inherited for ages. Traditional community reminds us of villages, even though not all of village communities are traditional. In a traditional community, somebody cannot be separated with his or her surroundings. They are connected with nature directly and openly. A person and a society are strongly connected with the universe. In a traditional community, the social culture is usually governed by tradition and belief, not laws and legal bills. ${ }^{33}$

Modern community values rationality more, and is highly opened to new changes. Modernist in a modern structure. Modern social structure is a network of connection between humans in a modern society, from which grow social, political, economical, and cultural regulations. In their work ethic they use the principal of rationality, analytic, empirical cause, and objective. Modern community is marked by the development in knowledge. ${ }^{34}$

Social changes could also be seen from a different time context, which is the social change from classical to contemporary. ${ }^{35}$ Social changes can also happen because of

${ }^{33}$ Pasaribu L.L. and B. Simandjuntak, Sosiologi Pembangunan (Bandung: Tarsito, 1986), p. 120.

${ }^{34}$ Ibid., p. 137.

${ }^{35}$ Classic, etymologically, means the past, which means that the classical age is the time when humans are still recently introduced to simple things and 
war. A war in a location can reduce the number of citizens in it, which is currently happening in some countries, or it can also cause a migration from one territory to the other which increases the amount of citizen, which in the end will finally cause a social change. It can also be caused by natural disaster. There are foreseen and unforeseen social changes. Unforeseen changes are changes that happen outside the view and will of the people. These unforeseen changes will usually create conflicts that damage the life of the society. ${ }^{36}$

The foreseen changes are the changes which have been predicted by people who are about to create change in society. These people are known as agent of change, a person of a group of individual whom have gained the trust of the people to lead one or more social institution. ${ }^{37}$

There are several factors that encourage and discourage the changes in social community: ${ }^{38}$

\section{a. The encouraging factors}

There are factors that boost the changes in society, such as:

1) Contact with another culture

Direct or indirect contact with another culture has boosted the change in social and culture, for example, the existence of a foreign individual within a community, or the role of internet in spreading a foreign culture.

2) Advanced formal educational system

technology. Contemporary derived from two words, co which means together and tempo which means time. Contemporary can be translated to "in the same time", "in time", "with time", "nowadays", and "this time". As such, contemporary mean modernistic. Contemporary refer to the time where we currently live in. Penyusun Kamus Pembinaan dan Pengembangan Bahasa, Kamus Besar Bahasa Indonesia (Jakarta: Balai Pustaka, 1997), p. 522.

${ }^{36}$ Abdulsyani, Sosiologi, p. 170.

${ }^{37}$ Ibid.

${ }^{38}$ Soerjono Soekanto, Sosiologi, p. 281. 
Education is an important factor for a society to advance. With it, human resources in a pace will be able to increase the prosperity of the society, because they are able to harness the natural resources more effectively and efficiently.

3) Aspiration toward another's works and the will to move forward

Every creation has a potential to develop humanity's civilization, such as telephone. In the beginning, people didn't view telephone as a great invention and they looked down on it.

4) Highly opened system of the layers of community An open end system made it possible to give a wide vertical social movements, which also means giving chance for individuals to move forward on their own will.

5) Heterogeneous inhabitant

A society with wide array of social, race, and ideological difference, have a high chance in causing conflicts within themselves. This condition motivates the changes within society.

b. The discouraging factors

1) The lack of connection with other society

Living in isolation made it hard for a society to know the development of the outside world which could have enrich their culture.

2) Overdue development of knowledge

This can be cause by the people living in isolation or under invasion from another society.

3) Traditional community 
The society's traditionalism, or an attitude that indulge in glorification of the past culture and the view that traditions absolutely cannot be changed, can delay the process of change.

4) Vested interest

A vested interest within a multi-layered society, will create a one or a group of individual that enjoys their positions, and don't have any desire for change.

5) The fear of disruption in cultural integration It is to be acknowledged that not all of cultural integration is perfect; some elements of classification have high degree of integrity.

\section{Education and Social Change}

Education has a close relevancy with every social change, whether in the form of individual dynamical change, or within a larger scale social change. Muhammad Abduh, as quoted by Azra, says that education is an effective tool to create changes. ${ }^{39}$ The social change process trough education needs to accommodate for people's social character. ${ }^{40}$ Within such significant functional framework, education needs to be positioned as a common sense development framework in a critical and creative manner. This is also the form of understanding and appliance of Islam. ${ }^{41}$

Education, said Abdul Munir Mulkhan, is the most effective form of social engineering model to prepare a shape of future society. According to Manan in Maslikhah, there are various problems that humans faced in their lives.

${ }^{39}$ Azyumardi Azra, Esei-esei Intelaktual Muslim dan Pendidikan Islam (Jakarta: Logos, 1999 ), p. 19.

${ }^{40}$ Muslikhah, Quo Vadis Pendidikan Multikultural: Rekonstruksi Sistem Pendidikan Berbasis Kebangsaan (Salatiga: STAIN Salatiga Press, 2007), p. 35.

${ }^{41}$ Ngainun Naim and Achmad Sauqi, Pendidikan Multikultural: Konsep dan Aplikasi (Yogyakarta: ar-Ruzz Media, 2008), p. 35. 
One of them, is how the people in society view their own people, how to work together, and interact as one nationality. The relationship between humans in a community has several central orientations. Those orientations are linealism, collateralism, and individualism in nature.

Second, in their live, every human face time. Every culture decides their dominant dimension of time, which became the unique aspect of that society. The most prominent time dimension, which became people's cultural orientation value, is those who have the past, present, and future orientation. A dominant time dimension will set the principle behind the attitude of the members of the society which will also influence the activities that are related to development.

Three, what is faced by the community have close relation with nature. The relation between human and nature can take form whether that human conquer nature, or nature conquer humans. Fourth, what is faced by humans is the need to work. Whether to working to support life, to look for positions, or to produce more works? Fifth, the thing faced by the people is the ownership of that culture itself. The existing alternative for cultural ownership is a continuum between the more materialism oriented, or the more spiritually oriented. Sixth, what humans face is the understanding of what is the essence of the humans themselves. Because of that, humans are willing to change according to that typical. Education is crucial to fulfill that wish.

From the result of observation and interview, we found that the education in al-Mubarok al-Islam salafiyah boarding school is implemented at all time. There are very little time to play or even watch television, since that kind of facility is not provided. 


\section{Al-Mubarok al-Islam Salafiyah Boarding School}

Jambi is a city that's strongly connected with Islam, this is proven with the large numbers of Islamic boarding school, and Islamic school in Jambi, one of the being the al-Mubarok al-Islam salafiyah boarding school.

Ma'had al-Mubarak al-Islami li Tahfizh al-Qur'an alKarim Tahtul Yaman Pelayangan is one of the boarding school that functions as a workshop to create students who can memorize the contents of Qur'an which located in Sekoja, Jl. K.H. Temunggung Jakfar Pelayangan Jambi, with No. NSSP 161161512157107012 P.P. al-Mubarok al-Islam. It is believed if one can memorize the contents of Qur'an, they will receive many benefits here and in the afterworld. This became the reason why "hafiz" (the people who memorize Qur'an) tried to keep their memorization of the Qur'an since they started until they die. But it is not wise to view this boarding school now without looking back at how it was started.

In 1996, al-Mubarok al-Islam Tahtul Yaman boarding school was founded by K.H. Mubarok bin Daud Ibrahim, and was aimed as an educational institution with self funding and supported by donations, also helped by the community in building the boarding school itself. Originally, there were only 70 students who learned in his house. Because of the growing number of students, the boarding school was built. Ustaz Mubarok faced many challenges during the process, but his faith and motivation gave him strength to finish it. The amount of students increased significantly. The total amount of santri in 2012 is about 800, which came from various regions, even another country, such as Malaysia. This 
is a fantastic number because not many Islamic educational institution can produce many hafiz with this many students. ${ }^{42}$

There are phases of building: the male dormitories, female dormitories, grand hall, study and sports room, mosque, administration office, equipment room, teacher's quarters, kitchen, and other supporting facilities. Al-Mubarok al-Islam Tahtul Yaman boarding school which was taken care by $\mathrm{H}$. Mubarok have produced many hafiz and hafizah (the female equation of hafiz), where the nurtured students have managed to remember all contents of the Qur'an and have been acknowledged by several other countries. Some of his chosen students were sent to Brunei, Malaysia, and even Saudi Arabia to become an imam over there. "Of course, those who we sent are the ones who have strength both on their memorization and knowledge." 43

Al-Mubarok al-Islam boarding school with its salafiyah type and hafiz specialty, which became the background of this boarding school's existence and the reasoning that memorizing Qur'an can bring benefit here and in the afterworld. As such, this boarding school has managed to produce many hafizes who can memorize and understand the contents of Qur'an.

Like how it was said by the leader of al-Mubarak boarding school, H. Mubarak, during the graduation, there were 29 students; 17 male and 12 female. "They have memorized Qur'an completely.” On further detail, 7 of them were from Muaro Jambi, 5 of them were from Sarolangun, 6 were from Merangin, 5 were from Tebo, 2 were from

${ }^{42}$ http://rumah tahfidz cinta rasul. blogspot. co. id/ 2012/12/ kesehajaanpesantren- penghapal-al-quran.html, and observation and interviews with ustaz in al-Mubarok al-Islam boarding school, on May 7, 2016.

${ }^{43}$ From observation and interview with the caretaker of al-Mubarok boarding school, ustad Muslimin Al Mubarok, in May 7, 2016. 
Batanghari, 1 from Jambi, 1 from Kerinci, and 2 from Riau. "Ma'had has made 163 hafizes from 163 students."

Many of the alumni of this boarding school are willing to serve there for two years to teach their juniors. Some of the alumni are also sent to Yemen with a scholarship to learn about Islam there for 4-7 years, to then go back and implement their knowledge. Many have also gone to Egypt, because they felt that the focus of their study fits to continue there. ${ }^{45}$

In the beginning, al-Mubarok salafiyah boarding school was an old-fashioned boarding school, but with the implementation of UUD 1945 which stated that one of country's duties is to educate its people, and because of that, every citizen have a right to receive proper education which goes along with the modern age. Boarding schools as an educational institution have managed to fulfill this duty. The history of boarding schools has proven that this institution has existed and was able to produce many great ulama, teachers, and mubalig which are heavily needed by the community.

In order to improve the role of boarding schools as an educational institution, many boarding schools have also implemented the Nine Year Education Program. This program was aimed to optimize the necessity to study formally for at least nine years. The bases of this policy are:

a. Government Regulations Number 55 Year 2007 about religious study and religion;

b. The agreement of national education minister and minister of religion, RI Number I/U/KB/2000 and

${ }^{44}$ From the leader of al-Mubarok boarding school, during the fourth Qur'an memorization graduation ceremony, in Ma'had al-Mubarak al-Islam, Tahtul Yaman, Pelayangan, Jambi.

${ }^{45}$ From interview with al-Mubarok al-Islam boarding school's caretaker, Ustaz Muslimin, in May 7, 2016. 
Number MA/86/2000 about salafiyah boarding school as a pattern for nine year education program;

c. The agreement of Dirjen Bimbaga Islam Depag and Dirjen Dikdasmen Depdiknas Number E/83/2000 and Number 166/C/KEP/DS-2000 about the guide on salafiyah boarding school as a basic educational institution;

d. Decicion of Dirjen Kelembagaan Agama Islam Number E/239/2001 about technical guidance on the implementation of basic formal education's necessity. The basic education necessity on boarding schools.

The nine year education program in salafiyah boarding school was written in the joint agreement of national education minister and the minister of religion Number $1 / \mathrm{U} / \mathrm{KB} / 2000$ and Number MA/86/2000. This policy was created during the presidency of K.H. Abdurrahman Wahid (deceased). The one who have a big role during the implementation of this policy was Prof. Dr. Yahya A. Muhaimin, M.A., who was, at the time, having the position as the national education minister, and Prof. Tolhah Hasan, M.A., who was, at the time, having the position as the minister of religion. This policy was also strengthened with the knowledge of Coordinating Minister for People's Welfare during K.H. Abdurrahman Wahid's presidency, which was Prof. Basri Hasanuddin, M.A., the decision was also applied in the agreement of Dirjen Binbaga Islam Department of Religion and Dirjen Dikdasmen's National Education Department, Number E/86/2000 and Number 166/C/ KEP/DS-2000 about the guide on salafiyah boarding school as a basic educational institution. ${ }^{46}$

\footnotetext{
${ }^{46}$ www.jabar.kemenag.go.id/file/dokumen/PedPenyeleWajarDikdasPPS.doc.
} 
With those policies, al-Mubarok al-Islam salafiyah boarding school Jambi gave the students a chance to follow the national examination held by Department of Religion on respective institution. Al-Mubarok al-Islam salafiyah boarding school also gave the chance to its students for them to be able to dompete in the modern world by giving them regular license, which during the national exam learning system was taught briefly for a few months before following the exam.

The evaluation result of their exam show that they bore no huge difference with another students who learned from normal schools, or another santri who learned within a modern boarding school which has a joint curriculum. Maybe this is what is called as God's help to those students who are close to him. That way, the alumni of al-Mubarok al-Islam salafiyah boarding school can continue their studies and compete in the universities that they dreamed of, especially Islamic universities. ${ }^{47}$

Salafiyah boarding schools are boarding schools which still keep its specialized boarding school system, whether from the aspect of their curriculum or learning method. The learning material of this this salafiyah boarding school includes Islamic religion knowledge, by using classical books in Arabic, based on the students' level of ability. The learning method uses wetonan, bandongan, and sorogan system. But nowadays there are many salafiyah boarding schools which use classical system.

Every Saturday night, the students learn in the boarding school's leader's house as a routine. On Thursday night, the students organize activities like mubadharah, Dhiba'an/ al-Barjanji, speen in Indonesian or foreign language, syarbil,

${ }^{47}$ From observation and interview with the caretaker of al-Mubarok boarding school, Ustaz Muslimin, in May 7, 2016. 
tilawah, etc., that's the schedule of the students of al-Mubarok salafiyah boarding school.

Aside from tahfizh Qur'an and book studies, this boarding school also provides computer to learn about technology, but currently, some of them are broken and not yet repaired. Furthermore, this boarding school also has a library with various books available to the students as reference.

Al-Mubarok al-Islam salafiyah boarding school has a really strict rule code that must be followed. All of these rules exist with the knowledge and agreement of the students, their parents, and signed upon a seal. ${ }^{48}$ As such, the students will have to follow these rules and accept the consequences for breaking them.

\section{Boarding Schools and Community's Social Change}

Jambi, also known as the city of castles, was formed since the existence of the Melayu Jambi Kingdom durin the $18^{\text {th }}$ century, along the Batanghari River. Jambi is also known as riverfront city, which has its own uniqueness. That uniqueness existed because of the Batanghari River, which separates jambi in two; the developing city and Sekoja which is the enclave region for people of Melayu Jambi.

The phrase "Jambi Kota Seberang" refers to the other side of Batanghari, which was known as "Jambi Seberang" or "Seberang Kota Jambi" actually have been decided since the time when Arifien Manap became a mayor. Nowadays, the Sekoja have developed more rapidly. ${ }^{49}$

The changes happening in the people nowadays are a normal symptom. The effects can quickly reach all layers of

\footnotetext{
${ }^{48}$ From interview with al-Mubarok al-Islam boarding school's teacher, Ustaz Shofiyah, in November 1, 2016.

${ }^{49}$ http://www.inilahjambi.com/seberanag-jambi-5/, Desember 28, 2015.
} 
the society, because of the modernization by using the media. With technology, communication can travel from an incident happening in one place, and it can reach a place faraway from there in a short time.

The people in sekoja have a really strong belief in Islam, because this place was where Islam first entered Jambi. A lot of boarding schools of various types existed in this region. As such, the people can choose the boarding schools with type that they want which fit their economy.

This salafiyah boarding school arrive with the salafi type and is always opened for the people from high layer of the community to below, and this boarding school provide the chance for them who are poor. It can be seen from the monthly fee of Rp 25.000 and the monthly fee for food with 3 meals a day is only Rp 40.000, and for those who are unable to pay, they can get it free. ${ }^{50}$

This salafiyah boarding school also gives a chance to the people in the community around it to study, so that it can strengthen the bond with the people. ${ }^{51}$

As we know there are a lot of people in the society who tried to invite kyai, ustad, or students of al-Mubarok alIslam to help with their celebration. Such as asking them to do speech, recitation, qiro'ah, memorization display, yasinan, tablilan, ta'ziyah, taking care of the deceased, aqiqah, Dhiba'an/ al-Barjanji, etc., the boarding school did the same thing as well by inviting the people to come to their celebrations, so that it will strengthen their bond. ${ }^{52}$

\footnotetext{
${ }^{50}$ From interview with al-Mubarok al-Islam boarding school's caretaker, Ustaz Muslimin, in October 1, 2016.

${ }^{51}$ From interview with al-Mubarok al-Islam boarding school's teacher, Ustad Isamaronia, in October 4, 2016.

${ }^{52}$ From interview with al-Mubarok al-Islam boarding school's caretaker, Ustaz Muslimin, in October 10, 2016.
} 
There are several responses from the al-Mubarok alIslam boarding school, such as:

a. The salafiyah boarding school was once an institution with no formal structure, and now it have a formal structure which can accommodate every aspects of the boarding school;

b. From the beginning, this boarding school was not intended to prepare able working force like how most normal school does. But the education system focuses on creating devoted students who can understand and implement Islam wisely. As the time goes, al-Mubarok al-Islam salafiyah boarding school started giving chance to its students to learn about regular school's subjects (by learning from books in library and the short course before exam) and to follow the national exam as well as having a general license which can be used to look for jobs. As such, the boarding school has a competitive quality in regular knowledge's aspects;

c. Salafiyah boarding school is known for its tight rule to not use the help of electronics such as hand phones, televisions, computers, and other similar medias which could give a negative impact to its students. But in order to use the media which can be very beneficial to them, the boarding school allows its students to use computers during tech classes.

Such are the responses of al-Mubarok al-Islam salafiyah boarding school, toward the modernization and the social changes of the society.

Based on the reasons above, it can be concluded that al-Mubarok al-Islam salafiyah boarding school, is still one of the "houses" that is still useful in improving the students mental and spiritual defense suitable with the changing times. 
Nowadays, salafiyah boarding schools become a reference to study for everyone and anyone from many layers of society without looking from their social aspects and statuses.

Even though modern education has entered alMubarok al-Islam salafiyah boarding school, but it doesn't erase its tradition, which is the boarding school's specialty. The pattern of living, thinking, feeling, and attitude within, will cause an outburst in each character's soul to be brave and the strength to never give up no matter the hardships, and these characteristics will help them to survive in all aspects of life. The pattern of living, thinking, feeling, and attitude within, is the soul of salafiyah boarding school which keeps it existing until now.

\section{Conclusion}

Boarding schools is one of Indonesia's oldest educational institutions, which became a central for pure religious activities (tafaqquh $\bar{f}$ ad-din) to spread Islam. Boarding schools, as indonesia's indigenous academic institution, is very helpful in producing many high quality generations. In their development, boarding schools evolved from the more traditionally oriented into modernly oriented, which makes nowadays boarding schools became divided into two big type of groups, the sala $\bar{f}$ (traditional) and khala $\bar{i}$ (modern). The region of Seberang Kota Jambi (Sekoja), Jambi Province, was known as one of the Islamic education and development central. Jambi is a region that strongly believes in Islam, this is proven by the large numbers of boarding schools; one of them is the al-Mubarok al-Islam salafiyah boarding school. Ma'had al-Mubarak al-Islami li Tahfizh al-Qur'an al-Karim Tahtul Yaman Pelayangan, is one of the boarding school that functions as a workshop to create students who can memorize the contents of Qur'an. 
There are several responses from the al-Mubarok alIslam boarding school, such as: (1) The salafiyah boarding school was once an institution with no formal structure, and now it have a formal structure which can accommodate every aspects of the boarding school. (2) From the beginning, this boarding school was not intended to prepare able working force like how most normal school does. But the education system focuses on creating devoted students who can understand and implement Islam wisely. As the time goes, al-Mubarok al-Islam salafiyah boarding school started giving chance to its students to learn about regular school's subjects (by learning from books in library and the short course before exam) and to follow the national exam as well as having a general license which can be used to look for jobs. As such, the boarding school has a competitive quality in regular knowledge's aspects. (3) Salafiyah boarding school is known for its tight rule to not use the help of electronics such as hand phones, televisions, computers, and other similar medias which could give a negative impact to its students. But in order to use the media which can be very beneficial to them, the boarding school allows its students to use computers during tech classes.

It is suggested that in their learning method, al salafiyah boarding school also pay attention to the socio-psychology of its students, which means that the students should be given an entertainment media, but under supervision. It is hoped that al-Mubarok boarding school also open itself to the changes in modern time, so it can increase the quality of its alumni, in order for them to be able to compete with other school to continue their studies onto universities. 


\section{REFERENCES}

Abdulsyani. Sosiologi Skematika: Teori, dan Terapan. Jakarta: Bumi Aksara, 2007.

Azra, Azyumardi. Esei-esei Intelaktual Muslim dan Pendidikan Islam. Jakarta: Logos, 1999.

Bakhtiar, W. Laporan Penelitian Perkembangan Pesantren di Jawa Barat. Bandung: Balai Penelitian IAIN Sunan Gunung Jati, 1990.

Daulay, Haidar Putra. Sejarah Pertumbuhan dan Pembaharuan Pendidikan Islam di Indonesia. Jakarta: Kencana, 2007.

Departemen Agama RI Direktorat Jenderal Kelembagaan Agama Islam, Direktorat Pendidikan Keagamaan dan Pondok Pesantren Proyek Peningkatan Pendidikan Luar Sekolah pada Pondok Pesantren, Pola Pengembangan Pondok Pesantren. Jakarta: Departemen Agama, 2003.

Departemen Agama RI. Pondok Pesantren dan Madrasah

Diniyah. Jakarta: Direktorat Jenderal Kelembagaan Agama Islam, 2003.

Dhofier, Zamakhsari. Tradisi Pesantren: Studi Tentang Pandangan Hidup Kyai. Jakarta: LP3ES, 1994.

Effendy, Bahtiar. Transformasi Pemikiran dan Praktek Politik Islam. Jakarta: Paramadina, 1998.

Grathoff, Richard. The Correspondence between Alfred Schutz and Talcott Parsons: the Theory of Social Action. Bloomington and London: Indiana University Press, 1978.

Haedari, Amin. Transformasi Pesantren, Pengembangan Aspek Pendidikan Keagamaan dan Sosial. Jakarta: LEKDIS dan Media Nusantara, 2006. 
Hasbullah. Sejarah Pendidikan Islam di Indonesia: Lintasan Sejarah Pertumbuhan dan Perkembangan. Jakarta: Raja Grafindo Press, 1999.

Koenig, Samuel. Mand and Society: the Basic Teaching of Sociology. New York: Barners and Noble, Inc., 1957.

L.L., Pasaribu and B. Simandjuntak. Sosiologi Pembangunan. Bandung: Tarsito, 1986.

Malik, Jamaludin. Pemberdayaan Pesantren. Yogyakarta: Pustaka Pesantren, 2005.

Maore, Wilbert E. Order and Change, Essay in Comparative Sosiology. New York: John Wiley and Sons, 1967.

Mastuhu. Dinamika Sistem Pendidikan Pesantren. Jakarta: INIS, 1994.

Muslikhah. Quo Vadis Pendidikan Multikultural: Rekonstruksi Sistem Pendidikan Berbasis Kebangsaan. Surabaya: STAIN Salatiga Press, 2007.

Muzakir, Ali. "Madrasah atau Pesantren?: Jatidiri dan Identitas Lembaga Pendidikan Islam di Jambi”. Paper on International Confrence on Jambi Studies, Jambi, November 21-24, 2013.

Nafi', M.D. Praktis Pembelajaran Pesantren. Yogyakarta: Instite for Training and Development Amherst, MA Forum Pesantren, and Yayasan Selasih, 2007.

Naim, Ngainun and Achmad Sauqi. Pendidikan Multikultural: Konsep dan Aplikasi. Yogyakarta: ar-Ruzz Media, 2008. Poerbakawatja. Pendidikan dalam Alam Indonesia. Jakarta: Gunung Agung, 1976.

Qamar, Mujamil. Pesantren dari Transformasi Metodologi Menuju Demokratisasi Institusi. Jakarta: Erlangga, 2005. Raharjo, Dawam. Pergulatan Pesantren. Jakarta: P3M, 1985. 
Ritzet, George and Douglas J. Goodman. Teori Sosiologi Modern. Jakarta: Kencana, 2010.

Soekanto, Soerjono. Sosiologi Suatu Pengantar. Jakarta: Rajawali Pers, 2010.

Sorokin, Pitirim A. Contemporary Sociologial Teories. New York: Harper and Brothers, 1928.

Stingl, Alexander. The Biological Vernacular: from Kant to James, Weber, and Parsons. Lampeter: Mellen Press, 2009.

Undang-undang No. 20 Tahun 2003 Tentang Sistem Pendidikan Nasional.

Yamin, Moh. Jambi: Profil Propinsi Republik Indonesia. Jakarta: Yayasan Bhakti Wawasan Nusantara, 1992. 